\title{
Leadership and Health: The Scientific Journal's Mission of Spreading Science in Times of Pandemic
}

\author{
Francisco J. Bonilla-Escobar. ${ }^{1,2,3,4}$
}

It has been 8 years since the International Journal of Medical Students published its first issue.' Since that time, hundreds of medical students have been influenced by the journal directly, and thousands more indirectly. Some of them have been members of our select team of Student and Associate Editors, some have been Ambassadors, and others authors, readers or fans on social media.

During these years, we have trained future leaders of medical science in the areas of scientific publication, editorial management, and editorial processing. This early training in research, during and even before medical school, is a way to bridge the physician-scientist gap worldwide.

We come from a legacy of brilliant medical students who put together, against so many difficulties, a scientific journal for medical students and young doctors. ${ }^{1}$ Our Editorial Board is made of top-tier international researchers. Similarly, the Editorial Team is full of brilliant and enthusiastic medical students and young physicians who volunteer their time to help other students get their manuscripts strong enough to be published; eventually, this promotes research by medical students worldwide. Our Ambassadors are increasing the reach of the journal and allowing students to gain access to something that not that long ago, and especially for underserved areas, seemed unachievable: the publication of medical student research.

Today, more than ever, the community of medical students and young physicians is at risk. Humanity is going through an unprecedented time for our generation. In this issue, we are highlighting experiences from medical students and young physicians around the globe during this COVID-19 pandemic. This journal is an avenue for the youngest generations to tell the world about their experiences during these difficult times and to show how our peers around the globe are going through similar situations; but we did this specially to highlight the positive aspects of such circumstances. In this issue, you will find the problems, options, perspectives, fears, happiness, opportunities, ironies, and the best that we all can identify and take out of this pandemic. ${ }^{2-17}$

I have not been immune to this situation. Even though I am sitting comfortably writing this editorial, when this situation started, I was in the US. Then, I moved to France to do a fellowship in research, and after the two countries closed their borders, I ended up in my home country, Colombia. I am lucky to be with my family and you can imagine the challenges that I went through moving back home after all the previous efforts to get into top educational institutions. I cannot complain much: my research is being done remotely, and I am participating in academic activities using one of the many programs that we have. But I have learned that not everything is about the "when" but about the "how". In the Experiences section of this issue, you will find that too.
We have witnessed the globe being polarized. Leaders are forgetting that the economy is sustained by the ones that it serves, the people, and people are forgetting that the healthcare professional is anything but their enemy. We, as future scientists, must never forget that we praise facts over assumptions, and do our work not because of the monetary reimbursement but to serve others. The former is a fact from which some governments have taken advantage of their health care workers, especially in low- and middle-income countries where virus exposure is high and health care workers lack the required living conditions to safely care for others.

We have witnessed how other journals, even the most renowned ones, have run to publish everything. We see authors repeating their cases in more than one article, and series of cases with low number of patients which are not providing any new knowledge about a common enemy. These are desperate times, but we have a moral duty as editors. More transparent science is required as well as higher ethical standards among researchers and scientists. We try to impress these values to our authors through a long and comprehensive editorial process and a declaration of transparency when submitting their articles..$^{18}$

We have not and we are not going to rush to get publications pertaining to COVID-19. Articles will still undergo a peer-reviewed process due to our responsibility as editors and future judges of what we did during these times. Everything would be much better if we were able to judge our current acts knowing what was about to come in the future.

This takes me to the last part of this editorial. Decision makers are responsible for the health of people. We have seen amazing examples of paternalistic health interventions. Yes, people are complaining and, in some cases, protesting, but lives are being saved by governments decisions. How will history judge those decision makers that did not listen to science? How would it be if governments assumed a more compromised attitude towards prevention and improving people's lifestyle, well-being and health status based on reliable evidence?

We are still far from seeing the end of the tunnel in this pandemic. Things are not going to be the same after this period of our human history. Nevertheless, we need to be sure that we are moving forward. There are several global and local efforts in the shape of collaborations, studies and trials to win the battle against this coronavirus. We have found that we can live without many things and that there are gaps in people's daily lives that we never thought about but that we have found solutions to, or that we are still in the process of finding out how to solve. This is a new opportunity for humanity to grow, and this is also an opportunity for the planet which has a chance to recover, at least a little, from the abusive way we inhabit it.

We will overcome this situation and bright things will come after. We just need to stay strong and together.

\footnotetext{
MD, MSc, PhD(c). Editor in Chief IJMS.

Department of Ophthalmology, University of Pittsburgh, Pittsburgh, PA, USA

3 Servicio de Oftalmología, Grupo de Investigación en Salud Ocular, GISOC-UV, Universidad del Valle, Cali, Colombia

4 SCISCO Foundation, Science to Serve the Community/Fundación SCISCO, Somos Ciencia al Servicio de la Comunidad, Cali, Colombia
}

\section{Correspondence:}

Francisco J. Bonilla-Escobar

Address: 1400 Locust St, Pittsburgh, PA 15219, USA 


\section{Editorial}

\section{References}

1. Bonilla-Velez J, Peña-Oscuvilca A, Sahin I, Cordoba-Grueso WS, Fernandez-Zapico ME. The International Journal of Medical Students, a Platform for Medical Student Research Worldwide. Int J Med Students. 2013;1(1):6-7.

2. Biavardi NG. Being an Italian Medical Student During the COVID-19 Outbreak. Int J Med Students. 2020 Jan-Apr;8(1):49-50.

3. Pagano G, Luglio G. Medical Education in Naples, Italy, at the Time of SARS-CoV2. Int J Med Students. 2020 Jan-Apr;8(1):51-53.

4. Siraj A, Khan MW. Uncertainty in the Air. In the Emergency Room with COVID-19 in Pakistan. Int J Med Students. 2020 Jan-Apr;8(1):54-55.

5. Komer L. COVID-19 amongst the Pandemic of Medical Student Mental Health. Int J Med Students. 2020 Jan-Apr;8(1):56-57.

6. Pacheco Carrillo AM. The Utility of Online Resources in Times of COVID-19: A Mexican Medical Student Point of View. Int J Med Students. 2020 Jan-Apr;8(1):58 59.

7. López-Ruiz E. Studying Medicine in Barcelona During the COVID-19 Pandemic. Int J Med Students. 2020 Jan-Apr;8(1):60-61

8. Nguyen Tran Minh D, Pham Huy T, Nguyen Hoang D, Quach Thieu M. COVID-19: Experience from Vietnam Medical Students. Int J Med Students. 2020 JanApr;8(1):62-63.

9. Zitoun OA. COVID-19 Pandemic: Other Perspective. Saudi Arabia. Int J Med Students. 2020 Jan-Apr;8(1):64-65.
10. Kalra T, Kalra N. COVID-19: Where Do We Go from Here? An Experience from Medical Students in India. Int J Med Students. 2020 Jan-Apr;8(1):66-67.

11. Leong J, Sarohia GS. A New Reality: Experiences from Canadian Clerkship Medica Students during COVID-19. Int J Med Students. 2020 Jan-Apr;8(1):68-69.

12. O'Connor-Terry C, Gowda T, Zuchelkowski B, Minney S, Kwon J. Medical Students Have a Powerful Role in Addressing Community Needs in the COVID-19 Pandemic: An Experience from the US. Int J Med Students. 2020 Jan-Apr;8(1):70-72.

13. Kapri P, Gadgile P. The Voice of a Psychiatry Resident Doctor During COVID-19 Outbreak in Mumbai, India. Int J Med Students. 2020 Jan-Apr;8(1):73-74.

14. Nulkar A. Lessons from COVID-19: The Perspective of an International Medical Student Back in the United States. Int J Med Students. 2020 Jan-Apr;8(1):75-76.

15. Liu BD. Being an American 2nd Year Medical Student in the COVID-19 Pandemic. Int J Med Students. 2020 Jan-Apr;8(1):77-78.

16. Samuthpongtorn C, Pongpirul K. Medical Students in Low- and Middle-Income Countries and COVID-19 Pandemic. Int J Med Students. 2020 Jan-Apr;8(1):79-81.

17. Chatterjee S. The COVID-19 Pandemic Through the Lens of a Medical Student in India. Int J Med Students. 2020 Jan-Apr;8(1):82-83.

18. Altman DG, Moher D. Declaration of transparency for each research article. BM] 2013 Aug 7;347:f4796.

\section{Acknowledgments}

To the IJMS Team and especially to Mihnea-Alexandru Găman for being such an amazing Scientific Editor.

Conflict of Interest Statement at Funding

The author has no funding, financial relationships or conflicts of interest to disclose.

Author Contributions

Writing - Original Draft Preparation and Writing - Review at Editing: FJBE

Cite as:

Bonilla-Escobar FJ. Leadership and Health: The Scientific Journal's Mission of Spreading Science in Times of Pandemic. Int J Med Students. 2020 JanApr;8(1):9-10 